\title{
The Improvement of The Endogenous Antioxidant Property of Stone Fish (Actinopyga lecanora) Tissue Using Enzymatic Proteolysis
}

\author{
Sara Bordbar, ${ }^{1}$ Afshin Ebrahimpour, ${ }^{1}$ Azizah Abdul Hamid, ${ }^{1}$ Mohd Yazid Abdul Manap, \\ Farooq Anwar, ${ }^{3}$ and Nazamid Saari ${ }^{1}$ \\ ${ }^{1}$ Department of Food Science, Faculty of Food Science and Technology, Universiti Putra Malaysia, \\ 43400 Serdang, Selangor, Malaysia \\ ${ }^{2}$ Department of Food Technology, Faculty of Food Science and Technology, Universiti Putra Malaysia, \\ 43400 Serdang, Selangor, Malaysia \\ ${ }^{3}$ Department of Chemistry, University of Sargodha, Sargodha 40100, Pakistan
}

Correspondence should be addressed to Nazamid Saari; nazamid@putra.upm.edu.my

Received 14 September 2012; Revised 11 January 2013; Accepted 11 January 2013

Academic Editor: Xudong Huang

Copyright (C) 2013 Sara Bordbar et al. This is an open access article distributed under the Creative Commons Attribution License, which permits unrestricted use, distribution, and reproduction in any medium, provided the original work is properly cited.

\begin{abstract}
The stone fish (Actinopyga lecanora) ethanolic and methanolic tissue extracts were investigated for total phenolic contents (TPCs) as well as antioxidant activity using 2,2-diphenyl-1-picrylhydrazyl ( $\left.\mathrm{DPPH}^{\circ}\right)$ radical scavenging activity and ferric reducing antioxidant power (FRAP) assays. Both extracts showed low amount of phenolics (20.33 to $17.03 \mathrm{mg}$ of gallic acid equivalents/100 g dried sample) and moderate antioxidant activity (39\% to $34 \% \mathrm{DPPH}^{*}$ radical scavenging activity and 23.95 to $22.30 \mathrm{mmol} / 100 \mathrm{~mL} \mathrm{FeSO}_{4} \mathrm{FRAP}^{\circ}$ value). Enzymatic proteolysis was carried out in order to improve the antioxidant activity using six commercially available proteases under their optimum conditions. The results revealed that the highest increase in antioxidant activity up to $85 \%$ was obtained for papain-generated proteolysate, followed by alcalase (77\%), trypsin (75\%), pepsin (68\%), bromelain (68\%), and flavourzyme (50\%) as measured by $\mathrm{DPPH}^{*}$ radical scavenging activity, whilst for the FRAP value, the highest increase in the antioxidant activity up to $39.2 \mathrm{mmol} / 100 \mathrm{~mL} \mathrm{FeSO}_{4}$ was obtained for alcalase-generated proteolysate, followed by papain $(29.5 \mathrm{mmol} / 100 \mathrm{~mL} \mathrm{FeSO})$, trypsin $\left(23.2 \mathrm{mmol} / 100 \mathrm{~mL} \mathrm{FeSO}_{4}\right)$, flavourzyme $\left(24.7 \mathrm{mmol} / 100 \mathrm{~mL} \mathrm{FeSO}_{4}\right)$, bromelain $\left(22.9 \mathrm{mmol} / 100 \mathrm{~mL} \mathrm{FeSO}{ }_{4}\right)$, and pepsin $\left(20.8 \mathrm{mmol} / 100 \mathrm{~mL} \mathrm{FeSO}_{4}\right)$. It is obvious that proteolysis of stone fish tissue by proteolytic enzymes can considerably enhance its antioxidant activity.
\end{abstract}

\section{Introduction}

Oxidative stress is recognized as the major cause of chronic diseases progression, such as cancer, hypertension, cardiovascular disease, stroke, arteriosclerosis, diabetes, and neurodegenerative disorders. This leads to the generation of highly reactive molecules which are responsible for the development of such diseases. Studies have revealed that the ingestion of antioxidant supplements or food containing antioxidants may reduce oxidative damages [1-3]. Natural antioxidants such as polyphenols, phytosterols, carotenoids, vitamins $\mathrm{C}$ and $\mathrm{E}$, tocopherols, herbal extracts like rosemary, sage, and tea extracts have been commercialized as alternatives to synthetic antioxidants. In addition, proteins and protein hydrolysates derived from milk, soy, egg, and fish have also been shown to exhibit antioxidant activity $[4,5]$.

There is a great potential for the development of antioxidants from marine resources. Sea cucumbers are from those marine organisms that are considered as one of the most valuable sources of structurally diverse bioactive compounds with immense nutraceutical, pharmaceutical, and cosmeceutical potentials [6]. Sea cucumbers are crucial as human food source, particularly in some parts of Asia [7]. Several unique biological and pharmacological activities, namely, antiangiogenic, anticancer, antimicrobial, antitumor, and wound healing, are due to appreciable amounts of 
bioactive compounds found in sea cucumber species, including triterpene glycosides (saponins), chondroitin sulfates, sulfated polysaccharides, and peptides [6]. Some species of sea cucumbers were shown to contain potential antioxidant activity that may have been attributed by the presence of some bioactives such as flavonoids and bioactive peptides [8-13].

Actinopyga lecanora (Jaeger, 1833) from the phylum Echinodermata, class Holothuroidea, family Holothuriidae is a light gray or brown sea cucumber commonly seen on many of the South Asia sea shores. A. lecanora is commonly known as stone fish, because it looks like a smooth stone when disturbed, bloating up into a rounded, smooth shape and retracting its tube feet. This sea cucumber is classified among the edible species harvested for the food trade [14]. Well-founded data on medicinal properties and bioactive compounds of stone fish has not yet been reported. Thus, the current study is investigated to explore this multipurposes marine invertebrate as a potential source of antioxidants. The stone fish was quantitatively evaluated for total phenolic contents and its endogenous antioxidant activity. Besides, the improvement of antioxidant properties via generating proteolysates as well as bioactive peptides, using enzymatic proteolysis was appraised.

\section{Materials and Methods}

2.1. Enzymes. The enzymes used for enzymatic digestion, namely, alcalase and flavourzyme were supplied by Novozymes (Denmark), bromelain and papain were purchased from Acros Organic, pepsin from porcine gastric mucosa was supplied by Merck (Germany), and Trypsin from beef pancreas was supplied by Fisher Scientific (UK).

2.2. Chemicals. Chemicals used for the assays were of the analytical grade, including Folin-Ciocalteau purchased from Fisher Scientific (UK) and o-phthaldialdehyde (OPA) and 1,1-diphenyl-2-picrylhydrazyl $\left(\mathrm{DPPH}^{\bullet}\right)$ reagent purchased from Sigma-Aldrich (USA). Glutathione and 2,4,6,-tri(2pycridyl)-s-triazine were purchased from Acros Organic.

2.3. Sample Preparation. Stone fish was purchased from Pantai Merdeka, in the Kedah state, Malaysia. The internal organs (stomach and intestine) were removed and rinsed with cold distilled water, then immediately frozen and stored at $-80^{\circ} \mathrm{C}$ until used.

2.4. Composition Analysis. The analysis of proximate compositions was carried out using the standard methods of AOAC (2002) [15]. Water content was determined using air oven method $\left(100^{\circ} \mathrm{C}\right.$ for $5 \mathrm{~h}$; AOAC number $\left.950.46 \mathrm{~B}\right)$ and ash using basic heating technique $\left(550^{\circ} \mathrm{C}\right.$ for $5 \mathrm{~h}$; AOAC number 920.15), and crude protein was determined by nitrogen combustion procedure (AOAC number 992.15) with conversion factor of $N \times 6.25$. The amount of total lipids was determined gravimetrically after the Soxhlet extraction of dried samples with hexane. All measurements were performed in triplicate.

2.5. GC/MS Analysis. The qualitative and quantitative analysis of the stone fish crude extract was carried out using a
GCMS QP5050A Shimadzu system consisting of an autosampler equipped capillary GC interfaced with an EI ionization quadrupole mass analyzer with a mass range of $900 \mathrm{Da}$ for identification purposes. Helium was used as carrier gas $(1 \mathrm{~mL} / \mathrm{min})$, and the column used was a Zebron ZB-FFAP fused silica capillary column $(30 \mathrm{~m} \times 0.25 \mathrm{~mm}$ I.D. $\times 0.25$ film thickness). The oven temperature was programmed as follows: the initial temperature was held for $5 \mathrm{~min}$ at $50{ }^{\circ} \mathrm{C}$ and then from $50^{\circ} \mathrm{C}$ to $250{ }^{\circ} \mathrm{C}$ at a rate of $6{ }^{\circ} \mathrm{C} / \mathrm{min}$ and maintained for $15 \mathrm{~min}$. Injector temperature was set to $250{ }^{\circ} \mathrm{C}$. The compounds were individually identified based on coelution and MS analysis, when possible peak relative retention times were adjusted with those of documented samples. Each determination was carried out in triplicate.

\subsection{Total Phenols Determination}

2.6.1. Ethanolic and Methanolic Extraction. The phenolic extraction was carried out according to the method of Mamelona et al. [9], with some modifications. Briefly, sea cucumber was first freeze-dried and turned into powder. About $10 \mathrm{~g}$ of sample was mixed with $500 \mathrm{~mL} 80 \%$ ethanol, and the same amount was mixed with $80 \%$ methanol; both were stirred continuously at $4{ }^{\circ} \mathrm{C}$ for $24 \mathrm{~h}$ in the dark, to avoid likely oxidation of sensitive compounds due to light and high temperature. After $24 \mathrm{~h}$, the supernatants were separated by centrifugation at $10,000 \times \mathrm{g}$ for $5 \mathrm{~min}$ and filtered using Whatman filter paper. The solvents were removed using rotary evaporator. Extracts were immediately frozen and kept at $-80{ }^{\circ} \mathrm{C}$ for further use.

Total phenolic contents of extracts were determined according to the method of Mamelona et al. [9], with some modifications, using the Folin-Ciocalteau phenol reagent. $100 \mu \mathrm{L}$ of extracts were transferred into the test tubes, and their volumes were made up to $500 \mu \mathrm{L}$ with deionized water. $1.25 \mathrm{~mL}$ of $20 \%$ aqueous sodium carbonate solution was added to the $250 \mu \mathrm{L}$ Folin-Ciocalteu reagent in a test tube and diluted 10 times with distilled water. The mixture was vortexed vigorously and held in the dark for $45 \mathrm{~min}$ at room temperature. The absorbance was recorded at $725 \mathrm{~nm}$ against a blank containing the same mixture except the sample that was replaced with deionized water. The total phenolic content was expressed as gallic acid equivalents (GAE) in milligrams per 100 gram of extract, using a calibration curve generated with 10-100 $\mu$ g of gallic acid standard solution (e.g., $\mu \mathrm{g} / \mathrm{mL}$ ). All measurements were performed in triplicate.

2.7. Proteolysis of Sea Cucumber Protein. Freeze-dried sample (5 grams) was autoclaved at $121^{\circ} \mathrm{C}$ for $15 \mathrm{~min}$ to inactivate endogenous enzymes and microorganisms. The autoclaved sample was then dialyzed for $28 \mathrm{~h}$ ( $12 \mathrm{~h}$ against distilled water and $16 \mathrm{~h}$ against reaction buffer) at $4{ }^{\circ} \mathrm{C}$ in the dark. After dialysis, sample was incubated in a water bath to reach the reaction temperature and mixed with proteolytic enzyme at a ratio of 1/100 (w/w, enzyme/substrate) and started to proteolyze under optimum condition of each enzyme (Table 1). First sampling was taken before adding enzyme as a negative control; the subsequent samplings were done at $1 \mathrm{~h}$ interval for the first $10 \mathrm{~h}$ of proteolysis and then once after $24 \mathrm{~h}$. 
TABLE 1: Optimum conditions used for enzymatic proteolysis of stone fish.

\begin{tabular}{lccc}
\hline Enzyme & Buffer $(50 \mathrm{mM})$ & $\mathrm{pH}$ & Temperature $\left({ }^{\circ} \mathrm{C}\right)$ \\
\hline Alcalase & Borate buffer & 7.9 & 55 \\
Bromelain & Acetate buffer & 4.5 & 50 \\
Flavourzyme & Phosphate buffer & 6.5 & 50 \\
Papain & Phosphate buffer & 6.5 & 55 \\
Pepsin & Acetate buffer & 3.6 & 37 \\
Trypsin & Phosphate buffer & 6.9 & 37 \\
\hline
\end{tabular}

Enzyme was re-added at every $5 \mathrm{~h}$ during the proteolysis. The samples were then immediately boiled at $100^{\circ} \mathrm{C}$ for $10 \mathrm{~min}$ in order to inactivate proteases. Proteolysates were then centrifuged at $10,000 \times \mathrm{g}$ for $20 \mathrm{~min}$ to separate insoluble and soluble fractions. The supernatants were collected and stored in a freezer at $-80^{\circ} \mathrm{C}$ for further use.

2.8. Peptide Content Determination and Proteolysis Profiling Using o-Phthaldialdehyde (OPA). The o-phthaldialdehyde (OPA) based spectroscopic assay was performed to measure proteolysis of sea cucumber tissue in bufferic solutions, as described by Church et al. [16] with some modifications. A fresh OPA solution was prepared as follows: $20 \mathrm{mg}$ sodium dodecyl sulfate (SDS) was added to $762 \mathrm{mg}$ sodium tetrahydroborate and the mixture adjusted to $15 \mathrm{~mL}$ with deionized water. $16 \mathrm{mg}$ OPA dissolved in $400 \mu \mathrm{L}$ ethanol along with $40 \mu \mathrm{L} B$-mercaptoethanol diluted in $5 \mathrm{~mL}$ deionized water also added to the mentioned mixture and the whole mixture was adjusted to a final volume of $20 \mathrm{~mL}$ with deionized water. $40 \mu \mathrm{L}$ sample was added directly to $300 \mu \mathrm{L}$ of OPA reagent in a 96-well plate, mixed and incubated for $2 \mathrm{~min}$ at room temperature, and then the absorbance was measured at $340 \mathrm{~nm}$ using ELISA plate reader (Power Wave $\times 340$, Biotek Inc.). The peptide content was measured based on glutathione calibration curve constructed in the range of $0-200 \mathrm{ppm}$. Adequate dilution was needed if the OPA value measured was over the linear range of standard curve. The test was carried out in triplicate.

\subsection{Antioxidant Activity}

2.9.1. 2,2-Diphenyl-1-picrylhydrazyl DPPH Radical Scavenging Assay. 2,2-Diphenyl-1-picrylhydrazyl $\mathrm{DPPH}^{*}$ radical scavenging activity for both extracts and proteolysates was determined according to the method of Bersuder et al. [17]. A volume of $500 \mu \mathrm{L}$ of each diluted sample was mixed with $1 \mathrm{~mL}$ of $20 \mathrm{mM} \mathrm{DPPH}^{*}$ in $80 \%$ ethanol. The mixture was then kept at room temperature in the dark for $60 \mathrm{~min}$, and the reduction of $\mathrm{DPPH}^{\circ}$ radical was measured at $517 \mathrm{~nm}$ using UV-Vis Double Beam spectrophotometer (UVD 2950, Labomed, Inc.). The $\mathrm{DPPH}^{\bullet}$ radical scavenging activity (\%) was calculated as follows:

Radical scavenging activity (\%):

$$
\frac{\text { Absorbance of control - Absorbance of sample }}{\text { Absorbance of control }} \times 100 \text {. }
$$

A lower absorbance of the reaction mixture indicated a higher $\mathrm{DPPH}^{\circ}$ radical scavenging activity. Gallic acid was used as a standard (positive control) for solvent extracts and glutathione for proteolysates. Distilled water was used as blank. The tests were carried out in triplicate.

2.9.2. Ferric Reducing Antioxidant Power (FRAP) Assay. The procedure described by Guoa et al. [18] was followed. Briefly, the FRAP reagent contained $2.5 \mathrm{~mL}$ of a $10 \mathrm{mmol} / \mathrm{L}$ TPTZ (2,4,6-tripyridyl-s-triazine, Sigma) solution in $40 \mathrm{mmol} / \mathrm{L}$ $\mathrm{HCl}$ plus $2.5 \mathrm{~mL}$ of $20 \mathrm{mmol} / \mathrm{L} \mathrm{FeCl}_{3}$ and $25 \mathrm{~mL}$ of $0.3 \mathrm{~mol} / \mathrm{L}$ acetate buffer, $\mathrm{pH}$ 3.6. The reagent was prepared freshly and kept warm at $37^{\circ} \mathrm{C}$. Aliquots of $40 \mu \mathrm{L}$ sample supernatant were mixed with $0.2 \mathrm{~mL}$ distilled water and $1.8 \mathrm{~mL}$ FRAP reagent, and the absorbance of reaction mixture at $593 \mathrm{~nm}$ was measured spectrophotometrically after incubation at $37^{\circ} \mathrm{C}$ for $10 \mathrm{~min}$. The $\mathrm{FeSO}_{4}$ was used as the standard solution. The final result was expressed as the concentration of antioxidants having a ferric reducing ability equivalent to that of $1 \mathrm{mmol} / \mathrm{L} \mathrm{FeSO}_{4}$. Adequate dilution was needed if the FRAP value measured was over the linear range of standard curve. The test was carried out in triplicate.

\section{Statistical Analysis}

Statistical analysis and the comparison between the groups were performed using one-way ANOVA followed by Tukey's test to identify differences between treatments at 5\% significant level, using Minitab version 14 (Minitab Inc., State College, PA, USA).

\section{Results and Discussion}

4.1. Proximate Composition. The proximate composition of freeze-dried stone fish is given in Table 2. The contents of moisture, ash, fat, protein, and fiber were 6.65, 15.32, $3.65,69.71$, and $4.97 \%$, respectively. The protein content on dry weight basis was relatively higher than that obtained from different species in previous studies [19-21] (Table 2). Accordingly, stone fish can be considered as a good source of protein.

\subsection{Identification of Antioxidative Compounds Using GC/MS.} The composition of the antioxidative compounds present in crude extract of stone fish tissue was determined by GC/MS (Figure 1). Compounds were identified by comparing with the data base which were in agreement with Mass spectral library. Different array of compounds identified were hydrocarbons, sulfur-containing compounds, terpenes, acids, alcohols, and phenols, which contribute to the antioxidant activity of stone fish (Table 3 ). The major components present in the stone fish tissue crude extract included dimethyl sulfoxide (RT: 12.877, peak area: 59.7\%), acetic acid (RT: 11.132, peak area: $4.2 \%$ ) and dimethyl methylphosphonate (RT: 16.614, peak area: $4.1 \%)$. The main component of stone fish tissue extract with the highest peak area of $59.7 \%$ identified by GC/MS was dimethyl sulfoxide, which is an amphiphilic compound with ability to dissolve lipophilic compounds [22]. 
TABLE 2: Composition of freeze-dried stone fish tissue in comparison with other species.

\begin{tabular}{lcccccc}
\hline Sea cucumber species & Water content (\%) & Ash (\%) & Fat (\%) & Protein (\%) & Fiber (\%) & Reference \\
\hline Actinopyga lecanora & $6.65 \pm 0.44^{*}$ & $15.32 \pm 0.16^{*}$ & $3.65 \pm 0.1^{*}$ & $69.71 \pm 0.25^{*}$ & $4.97 \pm 0.13^{*}$ & Present study \\
Holothuria scabra & $6-6.5$ & $17.91-44.53$ & $1.17-2.44$ & $39.77-60.18$ & - & {$[19]$} \\
Holothuria tubulosa & $8.28 \pm 0.23$ & $46.43 \pm 0.51$ & $0.71 \pm 0.12$ & $44.58 \pm 1.01$ & - & - \\
Holothuria polii & $10.23 \pm 1.03$ & $48.22 \pm 1.02$ & $0.55 \pm 0.12$ & $36.99 \pm 0.62$ & - & - \\
Acaudina molpadioides & 8.25 & 7.56 & 0.55 & 68.53 & $-20]$ \\
Apostichopus japonicus & 21.55 & 21.09 & 1.85 & 55.51 & {$[21]$} \\
\hline
\end{tabular}

All data were reported on dried basis.

${ }^{*}$ Mean $\pm \mathrm{SD}, n=3$.

TABle 3: Antioxidative compounds in stone fish crude extract detected by GC/MS.

\begin{tabular}{lcccc}
\hline $\begin{array}{l}\text { Peak } \\
\text { number }\end{array}$ & Compound name & $\mathrm{RT}^{*}$ & SI* $\left.^{*} \%\right)$ & $\begin{array}{c}\text { Peak area } \\
(\%)\end{array}$ \\
\hline 2 & Diacetone alcohol & 9.919 & 88 & 2.01 \\
4 & Acetic acid & 11.132 & 100 & 4.2 \\
9 & Dimethyl sulfoxide & 12.877 & 96 & 59.7 \\
10 & Boric acid & 13.364 & 88 & 2.99 \\
11 & Propenoic acid & 13.508 & 95 & 2.4 \\
15 & Butyl aldoxime & 15.167 & 91 & 3.4 \\
17 & Propanedioic acid & 16.509 & 73 & 1.69 \\
18 & Dimethyl methylphosphonate & 16.614 & 76 & 4.1 \\
22 & phenol & 17.692 & 81 & 0.28 \\
35 & Pyrrolidinedione & 22.108 & 92 & 1.7 \\
- & Other compounds & - & - & 4.70 \\
\hline
\end{tabular}

${ }^{*} \mathrm{RT}$ : retention time.

${ }^{*}$ SI: similarity index.

Dimethyl sulfoxide was reported as a potential source of antioxidant in recent studies [22, 23].

4.3. Antioxidant Activity and Total Phenols of Solvent Extracts. The natural extracts antioxidant properties are generally ascribed to redox reactions with some biocompounds present in the extracts such as phenolics, salt, sugars, carotenoids, ascorbic acid, and peptides in addition to some pigments such as gadusol. These compounds can neutralize free radicals by acting as rapid donors of a hydrogen atom to radicals [8-10]. Their presence in stone fish tissue was expected, since these natural molecules are relatively easy to assimilate. Moreover, main sources of sea cucumbers food are phytoplankton and particles derived from degrading marine macroalgae which are phenolic rich materials [8-10]. Therefore, the initial objective was to determine total phenolic content of the tissue extracts which could possibly contribute to the antioxidant activity.

The levels of total phenols from Atlantic sea cucumber, Cucumaria frondosa and three species of Malaysian sea cucumbers (Holothuria scabra, Holothuria leucospilota, and Stichopus chloronotus) have been reported by Zhong et al., Mamelona et al., and Althunibat et al. [8-10]. Based on the previous reports, most of the phenolic compounds in sea cucumber are hydrophilic compounds [8-10]. As solubility of antioxidants plays an important role in their antioxidative capacity, in this study the polar solvents including $80 \%$ ethanol and $80 \%$ methanol were chosen for the extraction

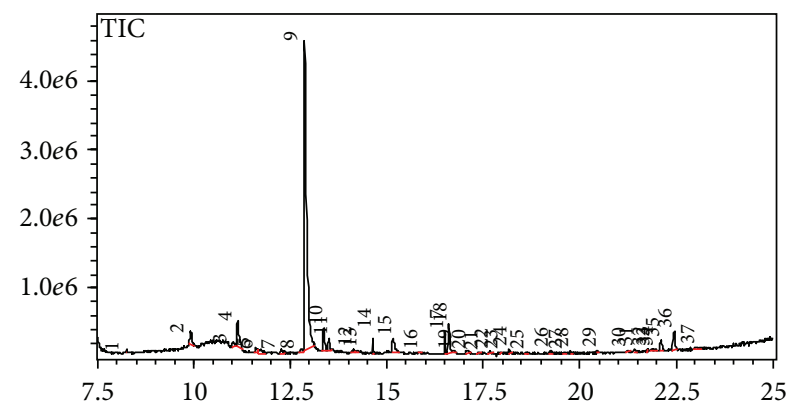

FIgURE 1: GC chromatogram of stone fish tissue extract. The detection limit for compounds identification is $10^{-9} \mathrm{~g}$.

of phenolics from stone fish. On the other hand, there is no single method that is able to provide a comprehensive and accurate profile of antioxidant activity, since different methods employ different action mechanisms such as termination of free radical mediated chain reaction, hydrogen donation, chelation of catalytic ions, and elimination of peroxides. Therefore, using multiple assays based on different antioxidant mechanisms would be crucial in providing a more reliable assessment of the samples antioxidant capacity $[4,24]$. Two methods were applied in the present research to measure antioxidant activity of stone fish extracts, namely, 2,2-diphenyl-1-picrylhydrazyl $\left(\mathrm{DPPH}^{*}\right)$ radical scavenging assay and the ferric reducing antioxidant power (FRAP) assay.

Total phenols in the samples varied from 20.33 to $17.03 \mathrm{mg}$ of gallic acid equivalents/100 g dried sample, depending on extracts involved (Figure 2), while the ethanolic extract showed significantly higher content of total phenolics $(P \leq$ 0.05). The $\mathrm{DPPH}^{\bullet}$ radical scavenging activity was $39 \%$ for ethanolic extract and $34 \%$ for methanolic extract. The $\mathrm{IC}_{50}$ of extracts were found to be $1.97 \mathrm{mg} / \mathrm{mL}$ for ethanolic extract and $1.7 \mathrm{mg} / \mathrm{mL}$ for methanolic extract. There was no significant difference $(P>0.05)$ in the antioxidant activity of both extracts. However, both extracts showed significantly $(P \leq$ $0.05)$ higher inhibition concentration compared to gallic acid $(0.05 \mathrm{mg} / \mathrm{mL})$. The results from ferric reducing antioxidant power assay also showed no significant difference $(P>0.05)$ between the ethanolic and methanolic extracts (23.95 and $22.30 \mathrm{mmol} / 100 \mathrm{~mL} \mathrm{FeSO}_{4}$, resp.). The results demonstrated a low contribution of phenolic compounds in antioxidant properties of stone fish extracts compared with other possible molecules such as carotenoids, ascorbic acid, proteins, and peptides such as glutathione. 


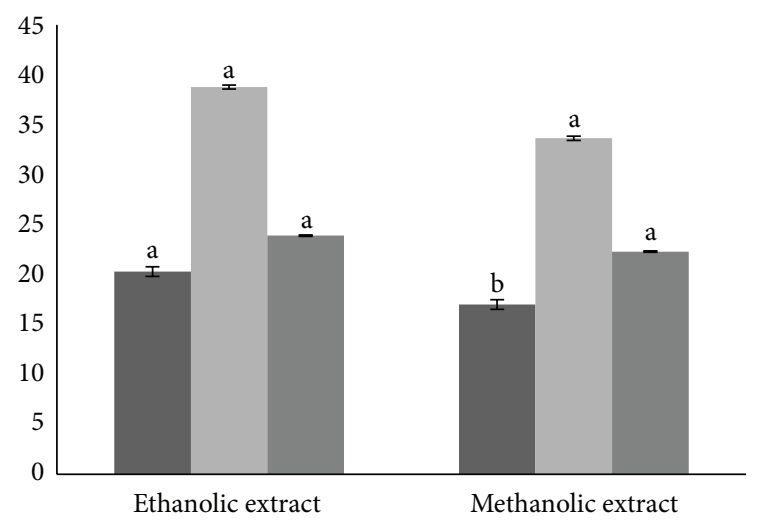

TPC (mg of GAE/100 g dried sample)
DPPH radical scavengin $(\%)$
FRAP reducing power $\left(\mathrm{mmol} / 100 \mathrm{~mL} \mathrm{FeSO}_{4}\right)$

FIGURE 2: Total phenolic content (TPC) (mg of gallic acid equivalent (GAE)/100 g dried sample), DPPH ${ }^{\bullet}$ radical scavenging activity (\%), and ferric reducing antioxidant power (FRAP) assay $(\mathrm{mmol} / 100 \mathrm{~mL}$ $\mathrm{FeSO}_{4}$ ) of ethanolic and methanolic extracts. Values were expressed as mean $\pm \mathrm{SD}, n=3$. Mean value within each group with different letters $(\mathrm{a}, \mathrm{b})$ indicated significant difference at $\mathrm{P} \leq 0.05$.

Based on the results, stone fish tissue with total phenols values ranging from 17.03 to $20.33 \mathrm{mg}$ of GAE/100 g may not be considered as a rich source of phenolic compounds as well as endogenous antioxidants compared to those from plants which are known for their high phenolic content and antioxidant properties like fruits, vegetables, and medicinal plants with total phenolic content which varied from 169 to $10548 \mathrm{mg}$ of GAE/100 $\mathrm{g}$ of dry sample [8-10]. However, the present findings are similar to those reported previously for other species of sea cucumber such as Cucumaria frondosa, Holothuria scabra, Holothuria leucospilota, and Stichopus chloronotus. [8-10].

With the aim of enhancing the antioxidant activity of stone fish tissue, the enzymatic proteolysis was carried out to digest the stone fish tissue proteins and generate proteolysates including bioactive peptides with higher antioxidative potentials.

4.4. Proteolysis Profiling and Peptide Content. Bioactive peptides play important roles in metabolic regulation and modulation and can be used as functional food ingredients, nutraceuticals, and pharmaceuticals to improve human health and prevent disease [25, 26]. Several studies have established that bioactive peptides have certain biofunctionalities that might serve therapeutic roles in the body systems $[26,27]$. They may act as alternatives to small molecule drugs. Moreover, they provide lots of advantages over conventional small molecules due to their high biological activity and biospecificity to targets, wide array of medicinal properties, low levels of toxicity, structural diversity, and absence or low levels of accumulation in the body tissues [28-30].

Bioactive peptides are inactive within the sequences of the parent proteins and need to be released somehow to exert various physiological functions [28, 31]. The enzymatic hydrolysis method is the most commonly used in the food. The careful choice of a suitable enzyme and digestion conditions such as temperature and $\mathrm{pH}$ for the optimal activity of enzyme and the control of hydrolysis time are crucial for obtaining proteolysates with desirable functional and bioactive properties [4].

In the present study, the proteolysis of stone fish tissue with 6 proteases commonly used in enzymatic proteolysis of animal products, including alcalase, bromelain, flavourzyme, papain, pepsin, and trypsin was carried out under their optimum conditions for $24 \mathrm{~h}$. The enzyme was re-added every $5 \mathrm{~h}$, in order to complete the digestion of stone fish tissue proteins. The extent of proteolysis was measured using spectrophotometric assay by the o-phthaldialdehyde (OPA) method. The content of peptides generated during digestion was also measured, using glutathione as a standard for calibration curve. The proteolysis curves of stone fish proteins within $24 \mathrm{~h}$ of digestion along with peptide content are demonstrated in Figure 3. The proteolysis was characterized by higher rates for alcalase, papain, and flavourzyme. Bromelain also showed a rapid rate for the first $2 \mathrm{~h}$, but subsequently the rate decreased. This could be due to the reduction in enzyme activity rather than completion of reaction, since it was again increased after re-adding enzyme after $5 \mathrm{~h}$ of proteolysis. On the other hand, proteolysis with trypsin started with a low rate while after readding enzyme the rate increased sharply. Again, it kept its constant increase by $9 \mathrm{~h}$ that it reached to the steady phase when the activity seemed to be finished due to the completion of reaction. Proteolysis with flavourzyme started with a high rate, and it constantly increased by $6 \mathrm{~h}$, when it reached to the steady phase.

Under the operating conditions used in the present study, according to the maximum absorbance measured at $340 \mathrm{~nm}$ (Figure 3), alcalase was the most efficient protease to digest the proteins and produce peptides $(14.18 \mathrm{mmol}$ glutathione/g dried sample) while pepsin showed the lowest efficiency to digest the sample and produce peptides $(3.15 \mathrm{mmol}$ glutathione/g dried sample). The maximum amount of peptide content observed from each enzyme was in the following descending order: alcalase $(14.18)<$ papain $(11.43)<$ trypsin $(9.06)<$ flavourzyme $(8.49)<$ bromelain $(7.92)<$ pepsin $(3.15)$ $\mathrm{mmol}$ glutathione/g dried sample. The enzymatic reaction seemed to be completed after $10 \mathrm{~h}$ of digestion, since the curves reached the steady phase, when no apparent hydrolysis took place, except for bromelain, which slightly extended to $24 \mathrm{~h}$.

The differences observed in the hydrolysis rate and pattern might be due to the differences in the properties of enzyme cutting sites as well as the accessibility of peptide bonds to each protease. Previous studies also revealed that the degree of hydrolysis of seafood materials using commercial enzymes was highly variable and depended on the nature of substrate, enzyme/substrate ratio and operating conditions [27].

4.5. Antioxidant Activity of Stone Fish Proteolysates. Antioxidant properties of proteolysates and bioactive peptides have been described in an increasing number of studies in recent 


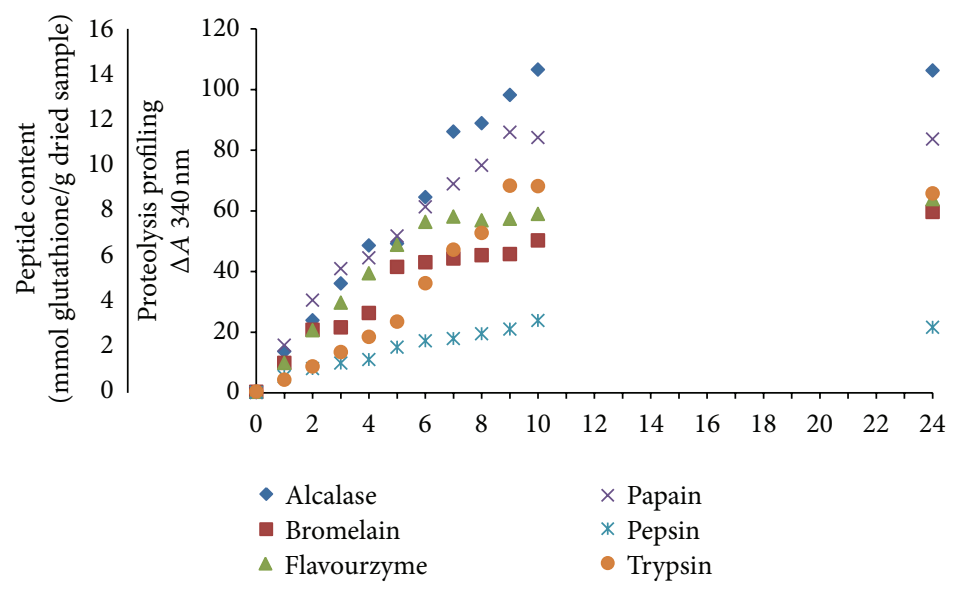

FIGURE 3: Proteolysis and peptide content ( $\mathrm{mmol} / \mathrm{g}$ dried sample) curves of stone fish proteolysates, generated by six enzymes under optimum conditions during $24 \mathrm{~h}$ of proteolysis. The OPA-peptide/protein complex absorbance was measured at $340 \mathrm{~nm}(\mathrm{mean} \pm \mathrm{SD}, n=3$ ).

years. A great deal of attention has also appeared to identify and assess antioxidative potential of bioactives derived from marine organism proteins and their possible applications as functional foods and nutraceuticals, to control various oxidative processes in the human body as well as in food [25$27,31]$. Since now, specific assays have not been developed or standardized to measure the antioxidative capacity of peptides or peptide mixtures. Therefore, assays that are commonly used for measuring antioxidative capacity of nonpeptidic antioxidants have been used in the literature to measure the antioxidative capacity of peptides as well [4]. In this study, we have reported our analytical results from $\mathrm{DPPH}^{\bullet}$ radical scavenging activity and ferric reducing antioxidant power (FRAP) of stone fish proteolysates obtained from various enzymatic treatments. The objective was to improve the antioxidant property of stone fish tissue by the proteolysis of its proteins and production of proteolysates and antioxidative bioactive peptides. The changes in the antioxidant activity of proteolysates during the $24 \mathrm{~h}$ of hydrolysis were also observed.

4.5.1. 2,2-Diphenyl-1-picrylhydrazyl (DPPH $\left.{ }^{*}\right)$ Radical-Scavenging Assay. One of the most common methods widely used to investigate the antioxidant capacity of natural compounds is 2,2-diphenyl-1-picrylhydrazyl $\left(\mathrm{DPPH}^{*}\right)$ free radical scavenging assay which relies on the reduction of $\mathrm{DPPH}^{*}$ which is a stable free radical that shows maximum absorbance at $517 \mathrm{~nm}$, in the presence of a hydrogen donating substances (antioxidants) [24].

The scavenging activity of stone fish protein hydrolysates for $\mathrm{DPPH}^{*}$ during $24 \mathrm{~h}$ of hydrolysis is shown in Figure 4. All treatments produced proteolysates with significantly $(P \leq$ $0.05)$ higher $\mathrm{DPPH}^{*}$ radical scavenging activities compared to the nonhydrolyzed sample. The radical scavenging curves of all proteolysates displayed a high rate for the first $1 \mathrm{~h}$ of hydrolysis. For alcalase and pepsin, the rate had a sharp increase by $5 \mathrm{~h}$ of hydrolysis, after which it decreased a bit and again increased until reaching to the steady phase. Proteolysates prepared by bromelain showed a high rate of activity for the first $2 \mathrm{~h}$, but the activity dramatically decreased by

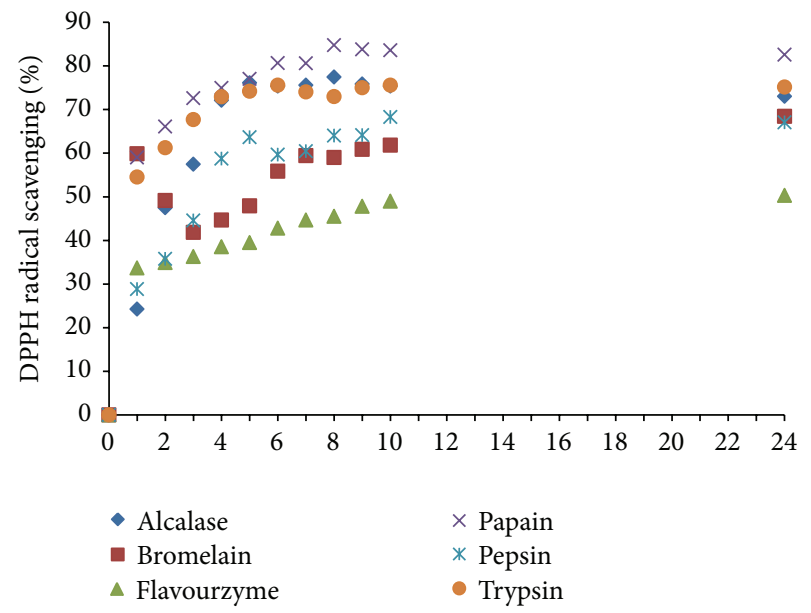

Figure 4: $\mathrm{DPPH}^{\bullet}$ radical scavenging activity (\%) of stone fish proteolysates derived from enzymatic digestion of stone fish tissue under optimum conditions for $24 \mathrm{~h}$. Absorbance was measured at $517 \mathrm{~nm}$ (mean $\pm \mathrm{SD}, n=3$ ).

$4 \mathrm{~h}$. The decrease in radical scavenging activity might be due to the generation of oxidant peptides, since bromelain is an endoprotease which cut the generated antioxidative peptides to smaller size. Then, the second phase of activity was again increased before reaching the plateau. The percentage of $\mathrm{DPPH}^{*}$ scavenging activities of different proteolysates varied from $50 \%$ to $85 \%$. Proteolysates prepared from papain showed significantly $(P \leq 0.05)$ the highest activity against $\mathrm{DPPH}^{\circ}(85 \%)$ followed by alcalase (77\%), trypsin (75\%), pepsin $(68 \%)$, bromelain $(68 \%)$, and flavourzyme (50\%). It has been reported that the type of enzyme employed in protein hydrolysis process has an effect on the antioxidant activity potential due to the enzyme mechanism of action. Besides, several findings have also suggested that peptide size and solubility, the amino acid composition, sequence and abundance of free amino acids may have a key role in determining the $\mathrm{DPPH}^{*}$ radical scavenging capacity $[1,4,31$, 32]. Differences in assay conditions such as $\mathrm{pH}$ and/or the peptide sequences involved during the experiment have also 
been found to contribute to the differences in $\mathrm{DPPH}^{\bullet}$ radical scavenging efficacies $[31,32]$.

$\mathrm{IC}_{50}$ (the concentrations of antioxidant substance scavenging $50 \%$ of $\mathrm{DPPH}^{*}$ radical) were determined for the proteolysates of each enzyme that showed the highest radical scavenging activity. The lowest $\mathrm{IC}_{50}$ value was obtained from both papain $(0.49 \mathrm{mg} / \mathrm{mL})$ and alcalase $(0.5 \mathrm{mg} / \mathrm{mL})$ proteolysates after $8 \mathrm{~h}$ of proteolysis, followed by trypsin $(0.69 \mathrm{mg} / \mathrm{mL}$ after $6 \mathrm{~h})$, pepsin $(1.54 \mathrm{mg} / \mathrm{mL}$ after $10 \mathrm{~h})$, bromelain $(2.01 \mathrm{mg} / \mathrm{mL}$ after $24 \mathrm{~h})$, and flavourzyme $(2.88 \mathrm{mg} / \mathrm{mL}$ after $24 \mathrm{~h})$. All proteolysates showed significantly $(P \leq 0.05)$ higher $\mathrm{IC}_{50}$ compared to glutathione $(0.006 \mathrm{mg} / \mathrm{mL})$ (Figure 5).

Our results revealed that the proteolysis of stone fish with papain could considerably increase the $\mathrm{DPPH}^{*}$ free radical scavenging activity of tissue extract from $34-39 \%$ up to $85 \%$ on the other hand, $\mathrm{IC}_{50}$ decreased from $1.97-1.7 \mathrm{mg} / \mathrm{mL}$ of tissue extract to $0.49 \mathrm{mg} / \mathrm{mL}$ of papain proteolysate. Stone fish proteolysates obtained from alcalase and papain digestion were found to possess strong radical scavenging capacity compared to the similar marine sources such as marine rotrifer (46-50\%) [33], sand eel (77\%) [34], red tilapia (IC $_{50}$ of $4.45 \mathrm{mg} / \mathrm{mL}$ ) [35], albone viscera $\left(\mathrm{IC}_{50}\right.$ of $4-7 \mathrm{mg} / \mathrm{mL}$ ) [36] and smooth hound $\left(\mathrm{IC}_{50}\right.$ of $\left.0.6 \mathrm{mg} / \mathrm{mL}\right)$ [37].

4.5.2. Ferric Reducing Antioxidant Power (FRAP) Assay. FRAP was used as the second assay for evaluating the ability of stone fish proteolysates to donate electron. FRAP assay uses antioxidants as reductants in a redox-linked colorimetric method, applying an easily reduced oxidant system present in stoichiometric excess. The principle involves the reduction of ferric tripyridyl triazine (Fe III TPTZ) complex to ferrous form (which has an intense blue color) at low $\mathrm{pH}$ which can be monitored by measuring the change in absorption at $593 \mathrm{~nm}$ [38].

Several studies have reported a direct correlation between antioxidative activities and reducing power of protein hydrolysates from different bioresources $[1,18,25,36]$. In this study, the ability of stone fish proteolysates to reduce $\mathrm{Fe}^{3+}$ to $\mathrm{Fe}^{2+}$ was determined. As displayed in Figure 6, the reducing power of all proteolysates increased as the proteolysis time increased up to $10 \mathrm{~h}$. The highest activity was achieved in proteolysates produced by alcalase with FRAP value $39.2 \mathrm{mmol} / 100 \mathrm{~mL} \mathrm{FeSO}_{4}$ obtained after $8 \mathrm{~h}$ of proteolysis followed by papain $\left(29.5 \mathrm{mmol} / 100 \mathrm{~mL} \quad \mathrm{FeSO}_{4}\right.$ after $8 \mathrm{~h})$, trypsin $\left(23.2 \mathrm{mmol} / 100 \mathrm{~mL} \mathrm{FeSO}{ }_{4}\right.$ after $\left.9 \mathrm{~h}\right)$, flavourzyme $\left(24.7 \mathrm{mmol} / 100 \mathrm{~mL} \mathrm{FeSO}{ }_{4}\right.$ after $\left.10 \mathrm{~h}\right)$, bromelain $\left(22.9 \mathrm{mmol} / 100 \mathrm{~mL} \mathrm{FeSO}_{4}\right.$ after $\left.24 \mathrm{~h}\right)$, and pepsin $\left(20.8 \mathrm{mmol} / 100 \mathrm{~mL} \mathrm{FeSO}_{4}\right.$ after $\left.9 \mathrm{~h}\right)$, respectively. There were no significant changes $(P>0.05)$ when the hydrolysis time was further continued from $10 \mathrm{~h}$ to $24 \mathrm{~h}$. Previous studies on ferric reducing antioxidant power (FRAP) of enzymatic proteolysates concluded that the reducing power activity was related to some factors including size and molecular weight of peptides, sequence of amino acids in peptides, number of hydrophobic amino acid, and amount of sulphur containing and acidic amino acids. Besides, the presence of some amino acids such as Leu, Lys, Met, Tyr, Ile, His, and Trp has been reported contributing to the strong reducing power of proteolysates $[4,25]$.

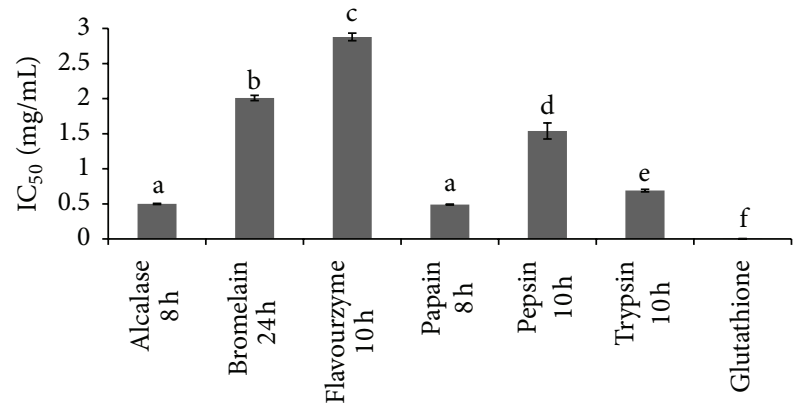

FIGURE 5: $\mathrm{IC}_{50}$ value of $\mathrm{DPPH}^{\bullet}$ radical scavenging activity for stone fish proteolysates $(\mathrm{mg} / \mathrm{mL})$. Glutathione was used as positive control. $\mathrm{a}, \mathrm{b}, \mathrm{c}, \mathrm{d}, \mathrm{e}$, and $\mathrm{f}$ indicated significant differences at the confidence level of $P \leq 0.05$ (mean $\pm \mathrm{SD}, n=3$ ).

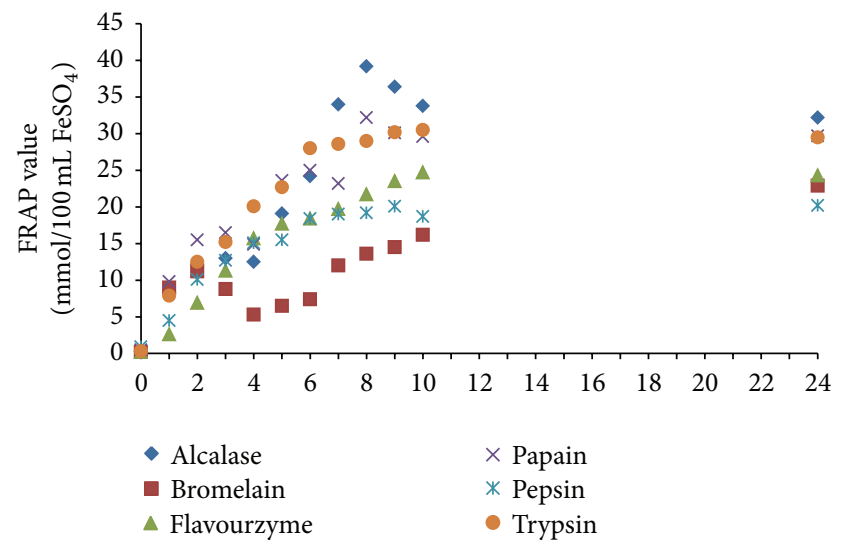

FIGURE 6: Ferric reducing antioxidant power (FRAP) of stone fish proteolysates derived from enzymatic digestion of stone fish tissue under optimum conditions for $24 \mathrm{~h}$. Absorbance was measured at $595 \mathrm{~nm}$, (mean $\pm \mathrm{SD}, n=3$ ).

Comparing the reducing power activity of stone fish proteolysates with those medicinal plants which are known for their high antioxidant properties showed that stone fish proteolysates reducing power activity were similar to those medicinal plants with low FRAP value $(1-5 \mathrm{mmol} / \mathrm{L}=10$ $50 \mathrm{mmol} / 100 \mathrm{~mL}$ ) [39]. However, they showed higher reducing power activity than fruits $[18,40]$, medicinal mushrooms [25], and other marine proteolysates [41] reported in previous studies.

Nevertheless, an increase in FRAP value of stone fish proteolysates was obtained from 22.30 to $23.95 \mathrm{mmol} / 100 \mathrm{~mL}$ $\mathrm{FeSO}_{4}$ of tissue extracts to more than $39.2 \mathrm{mmol} / 100 \mathrm{~mL}$ $\mathrm{FeSO}_{4}$ of alcalase proteolysates. The observed enhancement of both $\mathrm{DPPH}^{*}$ radical scavenging and FRAP value resulted directly from the generation of antioxidative bioactive peptides due to the enzymatic digestions and/or increased solvent exposure of some effective amino acids. While good antioxidant activity was observed from proteolysates, it is still not well understood how the composition of peptides influenced their ability to inhibit oxidation.

Comparing the results from $\mathrm{DPPH}^{\bullet}$ radical scavenging activity and FRAP reducing power of proteolysates demonstrated some differences between these two assessment 
methods of antioxidant activity in some cases. Since the mechanism of antioxidative action measured and/or reaction conditions used are different from one assay to another, a test sample may show different results for antioxidative capacity depending on the assay system used. For example, a good ferric reducer may not show a high activity in radical scavenging assays. Moreover, the conditions of the assay may affect the antioxidative capacity. For example, the reducing capacity of an antioxidant can be affected by $\mathrm{pH}$ of the assay media. Solubility of antioxidants in the reaction media also plays an important role in their antioxidative capacity $[1,4]$. In the present findings, moderate free radical scavenging and reducing power activities of crude alcoholic extracts of stone fish tissue were recorded, while those taken before adding enzyme including the bufferic tissue extracts showed no radical scavenging and very low reducing power activities. The reduction in antioxidant activity of bufferic extracts comparing to those alcoholic extracts could be due to the autoclaving process at high temperature along with dialysis, which led to the inactivation of some thermal sensitive and removal of water-soluble active constituents like enzymes, phenolics, flavonoids, sugars, salts, ascorbic acid, peptides, vitamins, and other endogenous antioxidative compounds from the sample.

4.6. Antioxidant Activity versus Proteolysis Time. The correlation between the degree of proteolysis for $24 \mathrm{~h}$ and the antioxidant activity of proteolysates measured by $\mathrm{DPPH}^{\circ}$ radical scavenging assay and FRAP value were determined. Results indicated strong correlations between both $\mathrm{DPPH}^{\circ}$ radical scavenging activity $\left(R^{2}>0.8\right)$ and FRAP reducing power $\left(R^{2} \leq 1\right)$ and degree of proteolysis. It could be suggested that enhancing the time of proteolysis led to the increase in the antioxidant activities. The increase in proteolysis time leads to the decrease in size of peptides. Therefore, proteolysates with smaller peptides may possess higher antioxidant activities. Some literature reports have shown a decrease in $\mathrm{DPPH}^{\bullet}$ radical scavenging capacity of proteolysates with increasing proteolysis time [42, 43]. Some other studies have shown a marked increase in the $\mathrm{DPPH}^{\circ}$ radical scavenging activity with the extended proteolysis [44, 45]. Our results indicated that, after about $7 \mathrm{~h}$ of proteolysis, the rate reached the steady phase when the prolongation in enzyme activity has no significant effect on the radical scavenging activity. This is in line with the previous reports suggesting the increase of $\mathrm{DPPH}^{\bullet}$ radical scavenging activity due to the extension of hydrolysis time $[44,45]$.

\section{Conclusion}

The bioactive peptides derived from marine resources with a wide array of biological activities and health beneficial effects have the potential to be exploited for nutraceuticals and functional food industry. The present study revealed that stone fish tissue could provide an appropriate antioxidative protection. These antioxidant activities increased even more after the digestion of tissue protein using enzymatic treatments, as a result of the production of bioactive peptides. Basically, the multifunctional nature of peptidic antioxidants, like having the ability to contribute other bioactivities, make them more attractive candidates than nonpeptidic antioxidants as dietary ingredients. The findings of the current research supported the Asian people beliefs about the health benefits of sea cucumbers in the folk medicine by approving the usefulness of stone fish biomolecules in preventing oxidation in vitro. This paper also highlighted the potential of stone fish-derived antioxidative proteolysates and bioactive peptides to be used in the food and beverages industries as natural alternative antioxidants to enhance the nutritional value and health benefits as well as the shelf life of the products.

\section{Acknowledgment}

The authors are grateful to the Malaysian Ministry of Science, Technology and Innovation for the financial support under the project no. 10-05-ABI-FB 037.

\section{References}

[1] B. Samadi and A. Ismail, "Antioxidative peptides from food Peptides Review," Peptides, vol. 31, no. 10, pp. 1949-1956, 2010.

[2] D. V. Ratnam, D. D. Ankola, V. Bhardwaj, D. K. Sahana, and M. N. V. R. Kumar, "Role of antioxidants in prophylaxis and therapy: a pharmaceutical perspective," Journal of Controlled Release, vol. 113, no. 3, pp. 189-207, 2006.

[3] S. J. Duthie, A. Ma, M. A. Ross, and A. R. Collins, "Antioxidant supplementation decreases oxidative DNA damage in human lymphocytes," Cancer Research, vol. 56, no. 6, pp. 1291-1295, 1996.

[4] A. G. P. Samaranayaka and E. C. Y. Li-Chan, "Food-derived peptidic antioxidants: a review of their production, assessment, and potential applications," Journal of Functional Foods, vol. 3, pp. 229-254, 2011.

[5] R. J. Elias, S. S. Kellerby, and E. A. Decker, "Antioxidant activity of proteins and peptides," Critical Reviews in Food Science and Nutrition, vol. 48, no. 5, pp. 430-441, 2008.

[6] S. Bordbar, F. Anwar, and N. Saari, "High-value components and bioactives from sea cucumbers for functional foods-a review," Marine Drugs, vol. 9, pp. 1761-1805, 2011.

[7] J. Wen, C. Hu, and S. Fan, "Chemical composition and nutritional quality of sea cucumbers," Journal of the Science of Food and Agriculture, vol. 90, no. 14, pp. 2469-2474, 2010.

[8] Y. Zhong, M. A. Khan, and F. Shahidi, "Compositional characteristics and antioxidant properties of fresh and processed sea cucumber (Cucumaria frondosa)," Journal of Agricultural and Food Chemistry, vol. 55, no. 4, pp. 1188-1192, 2007.

[9] J. Mamelona, É. Pelletier, K. Girard-Lalancette, J. Legault, S. Karboune, and S. Kermasha, "Quantification of phenolic contents and antioxidant capacity of Atlantic sea cucumber, Cucumaria frondosa," Food Chemistry, vol. 104, no. 3, pp. 1040-1047, 2007.

[10] O. Y. Althunibat, R. B. Hashim, M. Taher, J. M. Daud, M. A. Ikeda, and B. I. Zali, "In vitro antioxidant and antiproliferative activities of three malaysian sea cucumber species," European Journal of Scientific Research, vol. 37, no. 3, pp. 376-387, 2009.

[11] J. Mamelona, R. Saint-Louis, and E. Pelletier, "Nutritional composition and antioxidant properties of protein hydrolysates prepared from echinoderm byproducts," International Journal of Food Science and Technology, vol. 45, no. 1, pp. 147-154, 2010. 
[12] X. Zhou, C. Wang, and A. Jiang, "Antioxidant peptides isolated from sea cucumber Stichopus Japonicus," European Food Research and Technology, vol. 234, pp. 441-447, 2012.

[13] S.-K. Pan, D.-R. Yao, M.-Q. Zhou, and S.-J. Wu, "Hydroxyl radical scavenging activity of peptide from sea cucumber using enzyme complex isolated from the digestive tract of sea cucumber," African Journal of Biotechnology, vol. 11, pp. 1214-1219, 2012.

[14] http://makassartrepang.com/Stone-Fish.html.

[15] AOAC, Official Methods of Analysis of AOAC International No. 920. 05, 920. 39, 2002.

[16] F. C. Church, H. E. Swaisgood, D. H. Porter, and G. L. Catignani, "Spectrophotometric assay using o-pthaldialdehyde for determination of proteolysis in milk and isolated milk proteins," Journal of Dairy Science, vol. 66, pp. 1219-1227, 1983.

[17] P. Bersuder, M. Hole, and G. Smith, "Antioxidants from a heated histidine-glucose model system. I: investigation of the antioxidant role of histidine and isolation of antioxidants by high-performance liquid chromatography," Journal of the American Oil Chemists' Society, vol. 75, no. 2, pp. 181-187, 1998.

[18] C. Guoa, J. Yanga, Weia, J. Lia Y, J. Xua, and Y. Jiang, "Antioxidant activities of peel, pulp and seed fractions of common fruits as determined by FRAP assay," Nutrition Research, vol. 23, pp. 1719-1726, 2003.

[19] N. P. Ozzer, "Effect of the handling procedures on the chemical composition of sea cucumber," Turkish Journal of Fisheries and Aquatic Sciences, vol. 4, pp. 71-74, 2004.

[20] B. Sicuro, M. Piccinno, F. Gai et al., "Food quality and safety of Mediterranean Sea Cucumbers Holothuria tubulosa and Holothuria polii in Southern Adriatic Sea," Asian Journal of Animal and Veterinary Advances, vol. 7, pp. 851-859, 2012.

[21] J. Chen, "Overview of sea cucumber farming and sea ranching practices in China," Beche-de-mer Information Bulletins, vol. 18, pp. 18-23, 2003.

[22] C. Sanmart'ın-Suárez, R. Soto-Otero, I. Sánchez-Sellero, and E. Méndez-Álvarez, "Antioxidant properties of dimethyl sulfoxide and its viability as a solvent in the evaluation of neuroprotective antioxidants," Journal of Pharmacological and Toxicological Methods, vol. 63, no. 2, pp. 209-215, 2011.

[23] Z. Yuan, B. Zhao, and Y. Zhang, "Effects of dimethylsulfoxide on behavior and antioxidant enzymes response of planarian Dugesia japonica," Toxicology and Industrial Health, vol. 28, pp. 449-457, 2011.

[24] N. Abdullah, S. Ismail, N. Aminudin, A. S. Shuib, and B. F. Lau, "Evaluation of selected culinary-medicinal mushrooms for antioxidant and ACE inhibitory activities," Evidence-Based Complementary and Alternative Medicine, vol. 2012, Article ID 464238, 12 pages, 2012.

[25] L. Najafian and A. S. Babji, "A review of fish-derived antioxidant and antimicrobial peptides: their production, assessment, and applications," Peptide, vol. 33, pp. 178-185, 2012.

[26] D. H. Ngo, I. Wijesekara, T. S. Vo, Q. Van Ta, and S. K. Kim, "Marine food-derived functional ingredients as potential antioxidants in the food industry: an overview," Food Research International, vol. 44, no. 2, pp. 523-529, 2011.

[27] P. A. Harnedy and R. J. FitzGerald, "Bioactive peptides from marine processing waste and shellfish: a review," Journal of Functional Foods, vol. 4, pp. 6-24, 2012.

[28] D. Agyei and M. K. Danquah, "Industrial-scale manufacturing of pharmaceutical-grade bioactive peptides," Biotechnology Advances, vol. 29, pp. 272-277, 2011.

[29] F. Shahidi and Y. Zhong, "Bioactive peptides," Journal of AOAC International, vol. 91, no. 4, pp. 914-931, 2008.
[30] R. K. Scopes, "Methods for measuring protein concentration, Analysis-Measurements of protein and enzyme activity," in Protein Purification Principles and Practice, R. C. Charles, Ed., pp. 46-47, Boston University, Center for Advanced Biotechnology, Boston, Mass, USA, 3rd edition, 1993.

[31] J. T. Ryan, R. P. Ross, D. Bolton, G. F. Fitzgerald, and S. Stanton, "Bioactive peptides from muscle sources: meat and fish: a review," Nutrients, vol. 3, pp. 765-791, 2011.

[32] A. R. Ndhlala, M. Moyo, and J. Van Staden, "Natural antioxidants: fascinating or mythical biomolecules?" Molecules, vol. 15, no. 10, pp. 6905-6930, 2010.

[33] H. G. Byun, J. K. Lee, H. G. Park, J. K. Jeon, and S. K. Kim, "Antioxidant peptides isolated from the marine rotifer, Brachionus rotundiformis," Process Biochemistry, vol. 44, no. 8, pp. 842-846, 2009.

[34] W. S. Lee, J. K. Jeon, and H. G. Byun, "Characterization of a novel antioxidative peptide from the sand eel Hypoptychus dybowskii," Process Biochemistry, vol. 46, no. 5, pp. 1207-1211, 2011.

[35] M. Shamloo, J. Bakar, D. Mat Hashim, and A. Khatib, "Biochemical properties of red tilapia (Oreochromis niloticus) protein hydrolysates," International Food Research Journal, vol. 19, pp. 183-188, 2012.

[36] D. Y. Zhou, B. W. Zhu, L. Qiao et al., "In vitro antioxidant activity of enzymatic hydrolysates prepared from abalone (Haliotis discus hannai Ino) viscera," Food and Bioproducts Processing, vol. 90, pp. 148-154, 2012.

[37] A. Bougatef, M. Hajji, R. Balti, I. Lassoued, Y. Triki-Ellouz, and M. Nasri, "Antioxidant and free radical-scavenging activities of smooth hound (Mustelus mustelus) muscle protein hydrolysates obtained by gastrointestinal proteases," Food Chemistry, vol. 114, no. 4, pp. 1198-1205, 2009.

[38] http://www.scribd.com/doc/4940425/FRAP-Assay.

[39] V. Katalinic, M. Milos, T. Kulisic, and M. Jukic, "Screening of 70 medicinal plant extracts for antioxidant capacity and total phenols," Food Chemistry, vol. 94, no. 4, pp. 550-557, 2006.

[40] Y. S. Velioglu, G. Mazza, L. Gao, and B. D. Oomah, "Antioxidant activity and total phenolics in selected fruits, vegetables, and grain products," Journal of Agricultural and Food Chemistry, vol. 46, no. 10, pp. 4113-4117, 1998.

[41] M. C. Gómez-Guillén, M. E. López-Caballero, A. Alemán, A. López de Lacey, B. Giménez, and P. Montero, "Antioxidant and antimicrobial peptide fractions from squid and tuna skin gelatin," Sea by-Products as Real Material: New Ways of Application, pp. 89-115, 2010.

[42] V. Klompong, S. Benjakul, D. Kantachote, and F. Shahidi, "Antioxidative activity and functional properties of protein hydrolysate of yellow stripe trevally (Selaroides leptolepis) as influenced by the degree of hydrolysis and enzyme type," Food Chemistry, vol. 102, no. 4, pp. 1317-1327, 2007.

[43] A. E. Theodore, S. Raghavan, and H. G. Kristinsson, "Antioxidative activity of protein hydrolysates prepared from alkalineaided channel catfish protein isolates," Journal of Agricultural and Food Chemistry, vol. 56, no. 16, pp. 7459-7466, 2008.

[44] B. Li, F. Chen, X. Wang, B. Ji, and Y. Wu, "Isolation and identification of antioxidative peptides from porcine collagen hydrolysate by consecutive chromatography and electrospray ionization-mass spectrometry," Food Chemistry, vol. 102, no. 4, pp. 1135-1143, 2007.

[45] S. Raghavan, H. G. Kristinsson, and C. Leeuwenburgh, "Radical scavenging and reducing ability of tilapia (Oreochromis niloticus) protein hydrolysates," Journal of Agricultural and Food Chemistry, vol. 56, no. 21, pp. 10359-10367, 2008. 

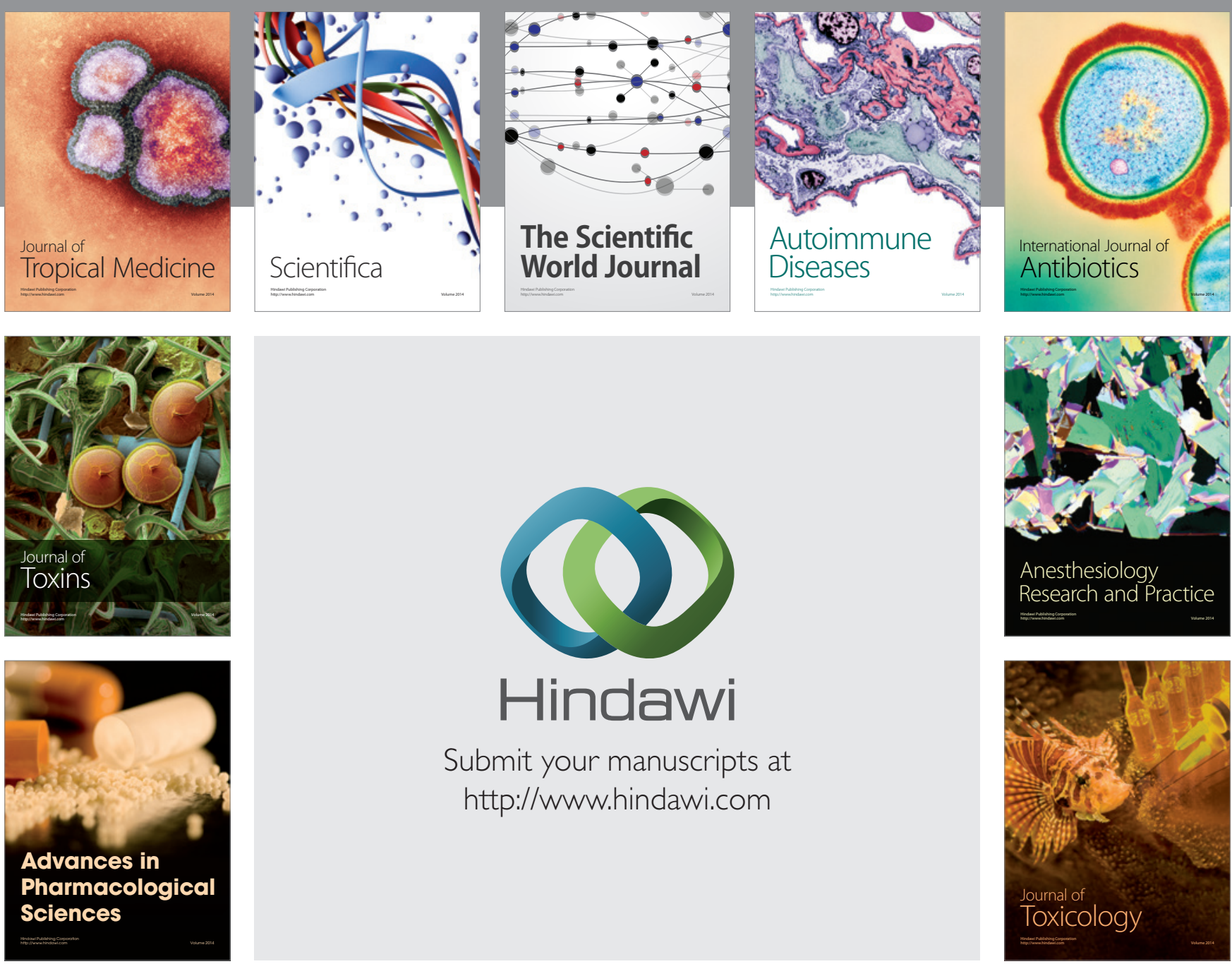

\section{Hindawi}

Submit your manuscripts at

http://www.hindawi.com
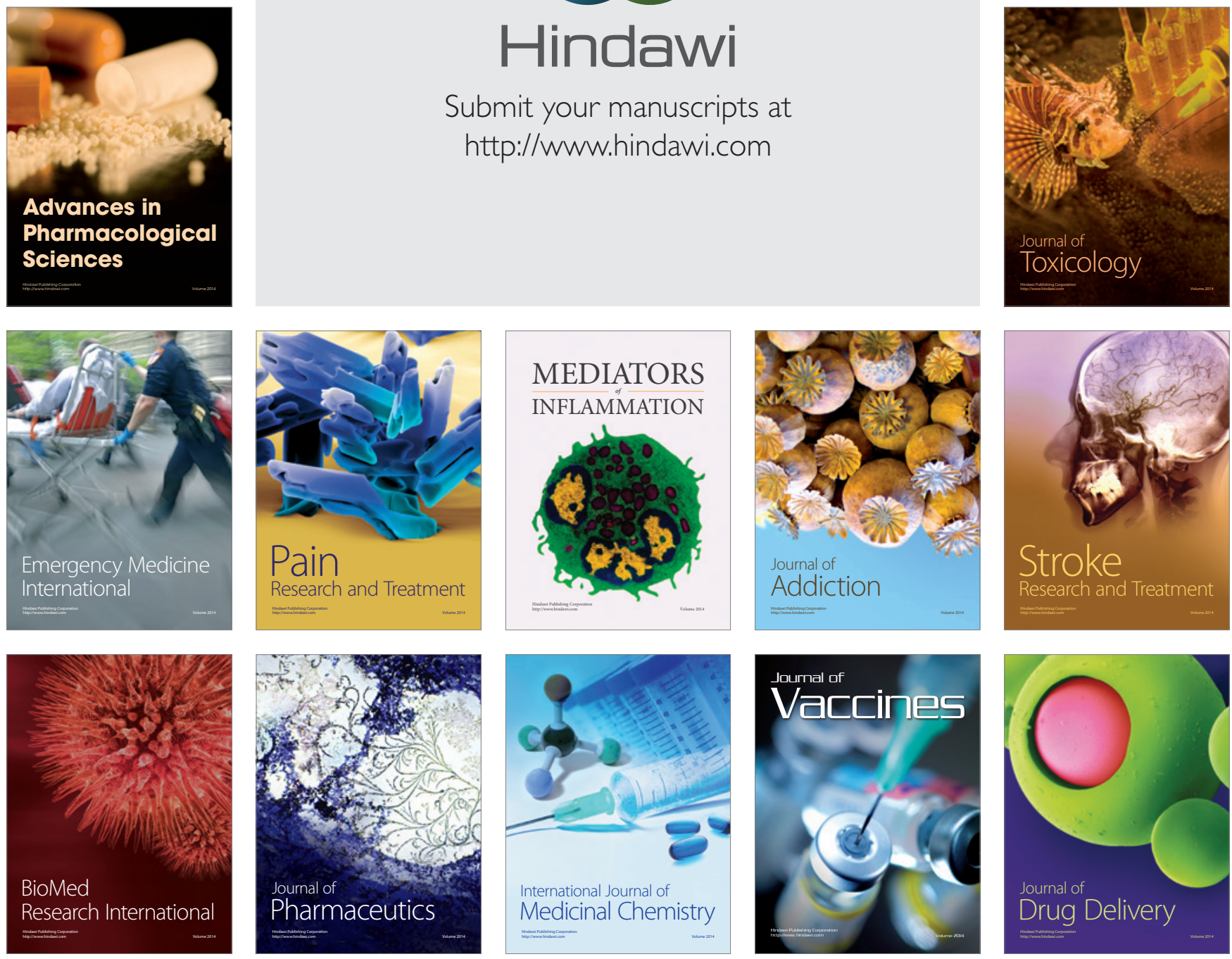